\title{
ANALYSIS OF REGULARITIES IN DISTRIBUTION OF EARTHQUAKES BY FOCAL DISPLACEMENT IN THE KURIL-OKHOTSK REGION BEFORE THE CATASTROPHIC SIMUSHIR EARTHQUAKE OF 15 NOVEMBER 2006
}

\author{
T. K. Zlobin ${ }^{1,2}$, A. Yu. Polets ${ }^{1,2}$ \\ ${ }^{1}$ Institute of Marine Geology and Geophysics, FEB RAS, Yuzhno-Sakhalinsk, Russia \\ ${ }^{2}$ Sakhalin State University, Yuzhno-Sakhalinsk, Russia
}

\begin{abstract}
The catastrophic Simushir earthquake occurred on 15 November 2006 in the Kuril-Okhotsk region in the Middle Kuril Islands which is a transition zone between the Eurasian continent and the Pacific Ocean. It was followed by numerous strong earthquakes. It is established that the catastrophic earthquake was prepared on a site characterized by increased relative effective pressures which is located at the border of the low-pressure area (Figure 1).

Based on data from GlobalCMT (Harvard), earthquake focal mechanisms were reconstructed, and tectonic stresses, the seismotectonic setting and the earthquakes distribution pattern were studied for analysis of the field of stresses in the region before to the Simushir earthquake (Figures 2 and 3; Table 1).

Five areas of various types of movement were determined. Three of them are stretched along the Kuril Islands. It is established that seismodislocations in earthquake focal areas are regularly distributed. In each of the determined areas, displacements of a specific type (shear or reverse shear) are concentrated and give evidence of the alteration and change of zones characterized by horizontal stretching and compression.

The presence of the horizontal stretching and compression zones can be explained by a model of subduction (Figure 4). Detailed studies of the state of stresses of the Kuril region confirm such zones (Figure 5).

The established specific features of tectonic stresses before the catastrophic Simushir earthquake of 15 November 2006 contribute to studies of earthquake forecasting problems. The state of stresses and the geodynamic conditions suggesting occurrence of new earthquakes can be assessed from the data on the distribution of horizontal compression, stretching and shear areas of the Earth's crust and the upper mantle in the Kuril region.
\end{abstract}

Key words: earthquakes, seismotectonics, tectonic stresses, Kuril-Okhotsk region, seismic foci zone.

Recommended by K.Zh. Seminsky 24 April 2012

Citation: Zlobin T.K., Polets A.Yu., 2012. Analysis of regularities in distribution of earthquakes by focal displacement in the Kuril-Okhotsk region before the catastrophic Simushir earthquake of 15 November 2006. Geodynamics \& Tectonophysics 3 (2), 115-127. doi:10.5800/GT-2012-3-2-0066.

\section{АНАЛИЗ ЗАКОНОМЕРНОСТЕЙ РАСПРЕДЕЛЕНИЯ ЗЕМЛЕТРЯСЕНИЙ ПО ТИПАМ ОЧАГОВЫХ ПОДВИЖЕК В КУРИЛО-ОХОТСКОМ РЕГИОНЕ ПЕРЕД КАТАСТРОФИЧЕСКИМ СИМУШИРСКИМ ЗЕМЛЕТРЯСЕНИЕМ 15.11.2006 ГОДА}

\author{
Т. К. Злобин ${ }^{1,2}$, А. Ю. Полец ${ }^{1,2}$ \\ ${ }^{1}$ Институт морской геологии и геофизики ДВО РАН, Южно-Сахалинск, Россия \\ ${ }^{2}$ Сахалинский государственный университет, Южно-Сахалинск, Россия
}


Аннотация: В зоне перехода от Евроазиатского континента к Тихому океану в Курило-Охотском регионе в районе Средних Курил 15.11.2006 г. произошло катастрофическое Симуширское землетрясение, после которого наблюдалась серия сильных землетрясений. Установлено, что подготовка этого землетрясения произошла на участке повышенного уровня эффективного всестороннего давления на границе с областью низких напряжений. При этом очаг был расположен на границе градиентной зоны (рис. 1).

Для оценки в регионе напряженного состояния, предшествующего Симуширскому землетрясению, по каталогу GlobalCMT (Harvard) построены механизмы очагов землетрясений и определены типы подвижек, изучены тектонические напряжения, сейсмотектоническая обстановка и распределение землетрясений по типам очаговых подвижек (рис. 2, 3, табл. 1).

Выявлено пять зон разных типов подвижек, из которых три вытянуты вдоль Курильской островной дуги. В них установлено закономерное распределение типов подвижек в очагах землетрясений. Закономерность выражается в концентрации в каждой из выделенных зон преимущественного типа подвижек (сбросов или взбросов). Это свидетельствует о чередовании и смене зон сжатия и горизонтального растяжения.

Наличие зон горизонтального сжатия и растяжения может быть объяснено моделью субдукции (рис. 4) и подтверждается при детальных исследованиях напряженного состояния на Курилах (рис. 5).

Установленные особенности тектонических напряжений перед катастрофическим Симуширским землетрясением 15.11.2006 г. способствуют решению проблемы прогноза землетрясений. Закономерности распределения горизонтального сжатия, растяжения и сдвигов в земной коре и верхней мантии региона позволяют судить о напряженном состоянии среды и указывают на геодинамические условия возникновения новых землетрясений.

Ключевые слова: землетрясения, сейсмотектоника, тектонические напряжения, Курило-Охотский регион, сейсмофокальная зона.

\section{1. ВВЕДЕНИЕ}

15 ноября 2006 г. в 11 ч 14 мин по Гринвичу в зоне перехода от Тихого океана к Евроазиатскому континенту произошло катастрофическое Симуширское землетрясение с магнитудой $M=8.3$. Тектоника, геологическое строение, динамика и сейсмичность этой зоны являются уникальными. Здесь, на границе гигантских морфоструктур, располагается Курило-Камчатская сейсмофокальная зона (СФЗ) и сопряженная с ней островная дуга, с которыми связаны многие кардинальные проблемы геотектоники и геодинамики планеты. Известно, что более 70 \% землетрясений Мира происходит в Тихоокеанском подвижном поясе, поэтому представляет большой интерес проведение здесь фундаментальных исследований, посвященных изучению сейсмической обстановки.

Симуширское землетрясение произошло в КурилоОхотском регионе в районе Средних Курил, восточнее Курильского острова Симушир на континентальном склоне. При этом почти через два месяца, 13 января 2007 г. в 4 час 23 мин, в этом же районе, но уже под глубоководным желобом произошло второе катастрофическое землетрясение с магнитудой 8.1 [Zlobin et al., 2008; Tikhonov et al., 2008].

По каталогу NEIC параметры первого землетрясения были $\varphi=46.592^{\circ}$ с.ш., $\lambda=153.266^{\circ}$ в.Д., второго $\varphi=46.243^{\circ}$ с.ш., $\lambda=154.524^{\circ}$ в.д. Глубина очага составила 10 км у обоих землетрясений. Моментные магнитуды $M_{\mathrm{w}}$ по оценке Сейсмологического центра Гарвардского университета (США) составили соответственно 8.3 и 8.1 [The Global Centroid Moment].

Для первого землетрясения (15.11.2006 г.) общая протяженность сейсморазрыва по оценке, приведенной И.Н. Тихоновым [Tikhonov et al., 2008], составила $L \sim 300$ км, ширина $W \sim 60$ км. При этом величина смещения по падению в плоскости сейсморазрыва была $d \sim 6.7$ м. Оно было пологим надвигом. Для второго землетрясения (13.01.2007 г.) смещения по косейсмическим измерениям соответствовали сбросу по плоскости сейсморазрыва северо-восточного простирания, круто падающей на северо-запад, и интерпретируются как сброс. Параметры сейсморазрыва соответственно были: $L \sim 180$ км, $W \sim 46$ км. Величина максимального смещения (сброс) составила $d \sim 5.1 \mathrm{м}$.

Изучение эпицентров и гипоцентров землетрясений 15.11.2006 г. и 13.01.2007 г., определенных по каталогу NEIC, показало, что они практически лежат в области изученного сейсмическими данными разреза земной коры. Это позволило сопоставить особенности глубинного строения (слои, скорости в них) по профилям вдоль и вкрест Средних Курил и очаги названных землетрясений [Zlobin et al., 2008]. Благодаря вышесказанному, стало возможным установить положение гипоцентров (центров центроидов) этих землетрясений в структуре земной коры.

В 2006-2009 гг. произошла серия сильных землетрясений с магнитудой от 6.5 до 7.4. [Zlobin et al., 2009]. Это были землетрясения 15.11.2006 г. $\left(M_{\mathrm{w}}=8.3\right)$, 13.01.2007 г. $\left(M_{\mathrm{w}}=8.1\right), 03.03 .2008$ г. $\left(M_{\mathrm{w}}=6.5\right), 15.01$. 2009 г. $\left(M_{\mathrm{w}}=7.4\right)$ и 07.04.2009 г. $\left(M_{\mathrm{w}}=6.9\right)$. Названные события сопровождались афтершоками с магнитудой до $M=5$ и более.

Для выяснения причин возникновения подобных сейсмических явлений большое значение имеет как изучение условий возникновения таких землетрясений 
и напряженного состояния среды перед этими событиями, так и исследование особенностей развития сейсмотектонической обстановки, подвижек в очагах землетрясений и закономерностей их смены.

Изложенное определило цель настоящей работы анализ сейсмической обстановки в регионе и закономерностей распределения типов очаговых подвижек, предшествующих этому катастрофическому землетрясению. Особое внимание уделено исследованию современной сейсмотектоники и последующему развитию событий.

\section{2. ФАКТИЧЕСКИЙ МАТЕРИАЛ И РЕЗУЛЬТАТЫ ИССЛЕДОВАНИЙ}

Изучение типов подвижек перед Симуширским землетрясением выполнено на основе анализа механизмов очагов землетрясений. Для этого рассмотрены каталоги СФ ГС РАH, NEIC, GCMT (Harvard). Эпицентры главного толчка и афтершоков приведены по каталогу службы NEIC, данные которого имеют наибольшую точность по сравнению с данными из других источников [Tikhonov et al., 2008]. Типы подвижек определены нами по общеизвестным критериям на основе решений механизмов очагов землетрясений по каталогу GlobalCMT (Harvard).

За весь период инструментальных наблюдений на Средних Курилах никогда не было землетрясений с магнитудой $M$ более 7.0-7.5, хотя такое событие С.А. Федотов прогнозировал каждые 5 лет с 1965 г. [Fedotov, Chernyshev, 1987]. Последним значительным землетрясением здесь было Симуширское землетрясение 9 января 1989 г. с $M=6.8$. Завершение афтершоковой деятельности после сильных событий происходит обычно в течение 3-10 лет [Aver'yanova, 1975]. Наше рассмотрение сейсмических явлений, предшествовавших катастрофическому землетрясению 11 ноября 2006 г., выполнено с 2000 г., т.е. почти через 10 лет после землетрясения 1989 г. Анализ всех землетрясений, имеющихся, обработанных и представленных в каталоге GlobalCMT (Harvard), продолжался в течение последующего 10-летнего периода.

Было изучено в регионе распределение землетрясений разных типов подвижек, и выполнены детальные исследования напряженного состояния в области Симуширского землетрясения 15.11.2006 г. Последние осуществлены в результате применения метода катакластического анализа совокупностей разрывных нарушений, разработанного Ю.Л. Ребецким [Rebetsky, 2007, 2009], что позволило установить следующее.

Преимущественным типом напряженного состояния в исследуемом районе для всех глубинных уровней является горизонтальное сжатие, т.е. типичная для субдукционных зон ориентация осей главных напряжений. Однако до Симуширского землетрясения 15.11.2006 г. отклонение от этого режима на всех глу- бинных диапазонах проявилось к северу-востоку от острова Симушир, на траверзе о. Шиашкотан. Здесь отмечаются два участка с преимущественно иной ориентацией осей главных напряжений. В афтершоковый период отклонение от режима горизонтального сжатия наблюдается на востоке в районе желоба, где прослеживается область растяжения, а к северу от нее область с типом напряженного состояния - поддвиг. В основном характер поля напряжений изменяется в районе желоба [Polets, 2011], что нашло свое подтверждение при дальнейшем проведении анализа региональных особенностей и закономерностей тектонических напряжений, выявленных на основе изучения механизмов очагов землетрясений.

Для исследуемого района в области подготовки Симуширского землетрясения 15.11.2006 г. на всех глубинах восточнее острова Симушир отмечен участок повышенного уровня относительного эффективного всестороннего давления $p^{*} / \tau_{f}$, граничащий на юге с областью низких напряжений. Области с пониженным уровнем относительного эффективного давления (0-4) с увеличением глубины расширяются и становятся более выраженными (рис. 1). Очаг землетрясения 15.11.2006 г. расположен в пределах этого участка, на границе градиентной зоны. Область подготовки землетрясения в целом достаточно однородна, при этом для всех глубинных уровней имеются довольно крупные участки, в пределах которых параметр эффективного всестороннего давления принимает значения, отвечающие среднему уровню 4-12. В афтершоковый период участки повышенного уровня эффективного всестороннего давления $p^{*} / \tau_{f}$ отмечены вблизи желоба, южнее о. Шиашкотан (рис. 1) [Polets, 2011]. Отметим, что раньше подобные, но менее детальные работы по реконструкции полей напряжений при изучении напряжений земной коры северо-западного участка Тихоокеанской сейсмоактивной области в районе Курило-Камчатской дуги были выполнены Ю.Л. Ребецким [Rebetsky, 2007].

В целом в Курило-Охотском регионе для оценки сейсмотектонической обстановки и ее изменений, предшествовавших Симуширскому землетрясению 15.11.2006 г., в последующие годы было исследовано распределение разных типов подвижек в очагах землетрясений и закономерности их смены.

Для этого рассмотрено и проанализировано 515 событий, произошедших с 2000 до 2010 г. В результате было установлено распределение очагов землетрясений, построена карта эпицентров с указанием типа подвижек (рис. 2) и три проекции очагов землетрясений по направлению, ортогональному положению Курило-Камчатской дуги (рис. 3).

После их совместного анализа можно отметить следующее. Основное число современных землетрясений с определенными механизмами очагов произошло на глубинах до 80 км в юго-восточной приокеанической 


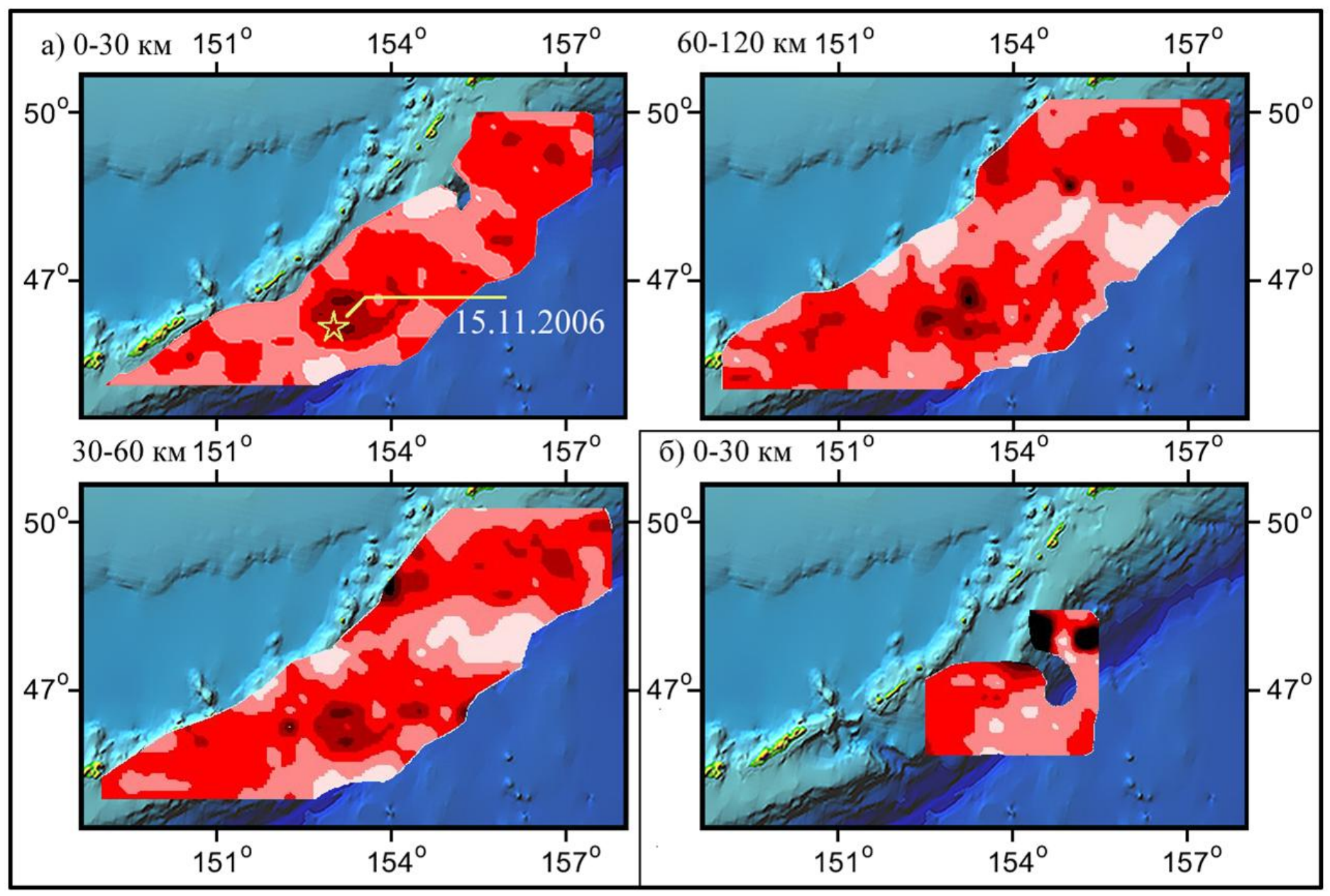

Относительное эффективное всестороннее давление $>20 \square$ 16-20 $\square$ 12-12 $\square$ 0-4

Рис. 1. Распределение относительного эффективного всестороннего давления $p^{*} / \tau_{f}: a-$ до землетрясения 15.11.2006 г., б - после землетрясения 13.01.2007 г. [Polets, 2011].

Fig. 1. The pattern of relative effective omnidirectional pressure, $p^{*} / \tau_{f}: a$ - before the Simushir earthquake of 15 November 2006 , and $b-$ after the earthquake of 13 January 2007 [Polets, 2011].

части рассмотренного региона, как и общее количество землетрясений за все годы по всем известным каталогам (СФ ГС РAH, NEIC, GCMT и др.). При этом подвижки в очагах большинства землетрясений на этих глубинах (246 из 312) представляли собой взбросы и пологие надвиги (рис. 2). Вопрос о выборе типа подвижки решался по классификации М.И. Стрельцова [Poplavskaya et al., 1991].

В соответствии с положением эпицентров вкрест простирания СФЗ с юго-востока на северо-запад, можно выделить три зоны, вытянутые вдоль глубоководного желоба и островной дуги (см. рис. 2).

Юго-восточная зона (№ 1 на рис. 2), шириной 80100 км, расположена в районе глубоководного желоба и восточнее под его приокеаническим склоном. Она характеризуется сбросовыми подвижками и, по всей видимости, находится в условиях растяжения. На раз- резе СФЗ (рис. 3) видно, что гипоцентры землетрясения здесь расположены в основном на глубинах до 50 км, т.е. в земной коре и самом верхнем слое верхней мантии.

Следующая основная зона (№ 2 на рис. 2), шириной около 100-180 км, расположена западнее вышеназванной зоны, между островной дугой и желобом под приостровным, склоном. В этой наиболее мощной зоне произошла большая часть землетрясений. В основном здесь определяются подвижки типа взброса и пологого надвига (из анализа механизмов очагов следует, что почти в каждом очаге по одной нодальной плоскости возможна подвижка типа взброса, по другой - пологого надвига, что говорит о преобладающих напряжениях горизонтального сжатия).

Далее к северо-западу, непосредственно под островами, установлена третья зона (№ 3 на рис. 3), также 


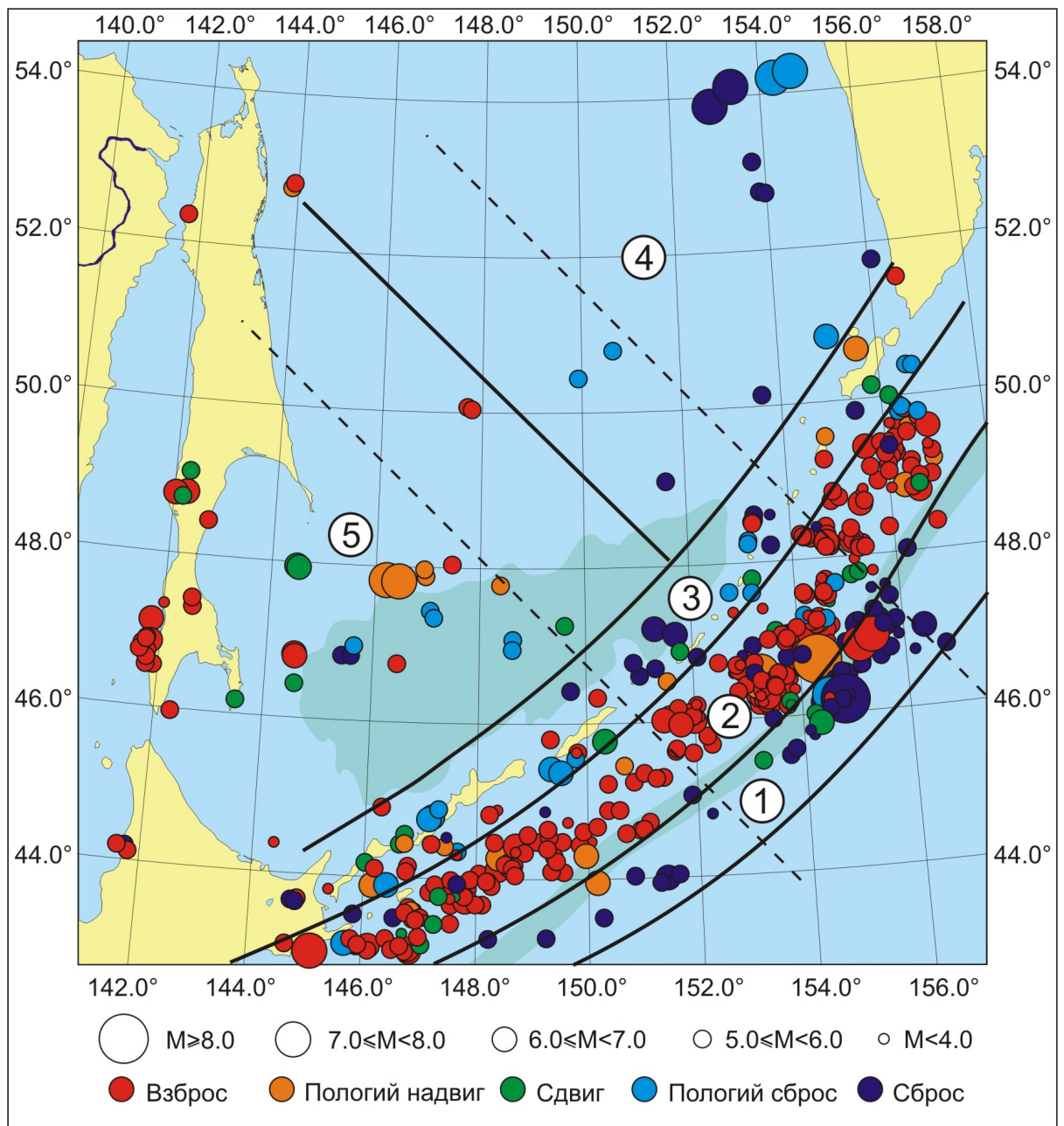

Рис. 2. Карта распределения типов подвижек в очагах землетрясений Курило-Охотского региона согласно данным GCMT.

Fig. 2. Distribution of seismic dislocation in the Kuril-Okhotsk region, according to GCMT data.

примерно 100-километровой ширины. Однако гипоцентры землетрясений здесь расположены примерно на глубине 80-150 км (рис. 3, $a-8$ ). Особенно явственно концентрируются очаги землетрясений зоны № 3 в районе Средних Курил (рис. 3, б). Здесь, как и в первой зоне, землетрясения характеризуются в основном нормальными и пологими сбросами. Они установлены под Средними Курильскими островами - Черные Братья, Симушир, Кетой, Расшуа и под проливами Буссоль и Крузенштерна, однако фиксируются и в районе северного о-ва Парамушир, а также под южными островами (Итуруп, Уруп).

Таким образом, с юго-востока на северо-запад выделено чередование трех основных зон. Первая (внешняя) и третья (внутренняя) области, вытянутые вдоль дуги в северо-восточном направлении, являются зонами горизонтального растяжения. Вторая (центральная) зона, расположенная между ними, - зона горизонтального сжатия. Естественно, на всей протяженности названных зон типы подвижек полностью не сохраняются. Взбросы и сбросы местами перемешиваются, но доминирующий тип подвижек проявляется достаточно хорошо. Аномалия в распределении типов подвижек отмечается в районе Центральных Курильских островов, где во второй зоне расположено большое число сбросов. По всей видимости, они связаны с серией Симуширских землетрясений 2006-2009 гг. В то же время в северной части восточнее о-вов Шиашкотан Парамушир наблюдается большая группа взбросов, которые находятся в зоне № 2, а также частично восточнее, в зоне № 3.

Сложное строение зоны № 3 в южной части дуги под о-вом Хоккайдо (в его северо-восточной части), а также в районе о-вов Итуруп и, особенно, Кунашир затрудняет однозначное определение доминирующего типа подвижки на этом участке зоны. Здесь наряду со сбросовыми подвижками и сдвигами присутствуют и взбросы.

В пределах рассматриваемой площади северо-западнее трех основных вышеописанных зон, вытянувшихся вдоль Курильской островной дуги (КОД), число обработанных событий с установленными и проинтер- 
a

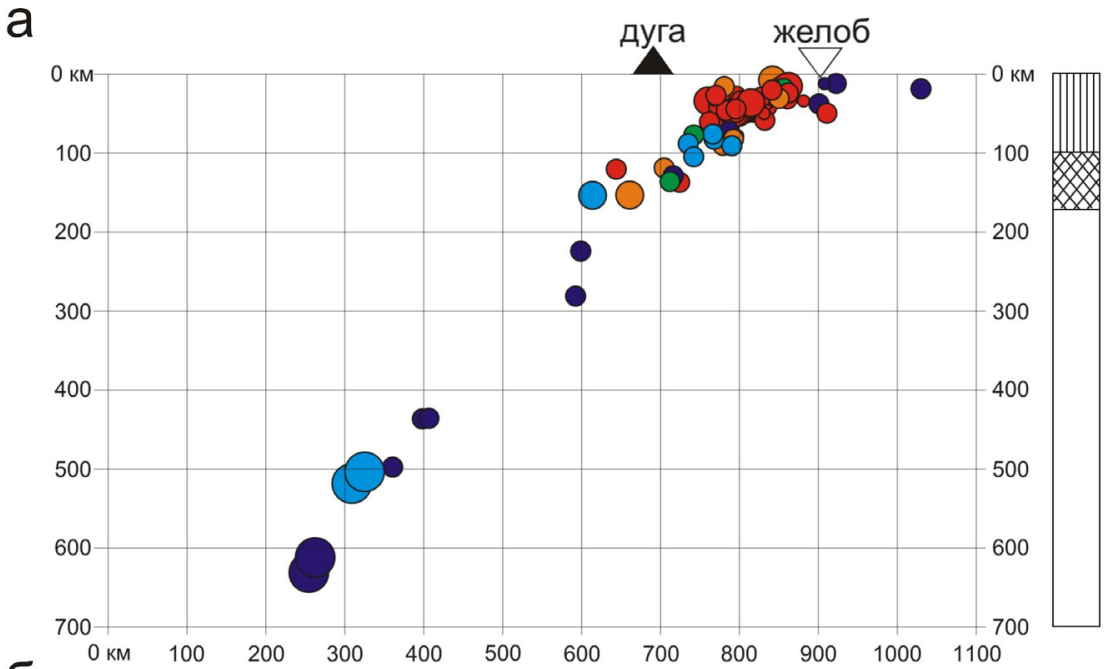

6

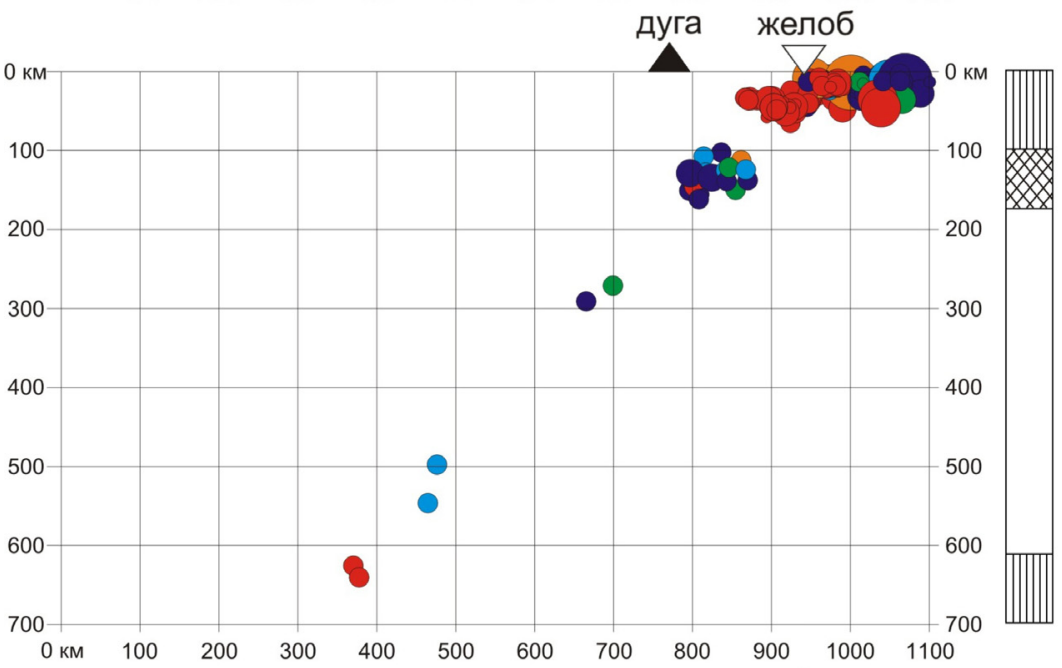

B

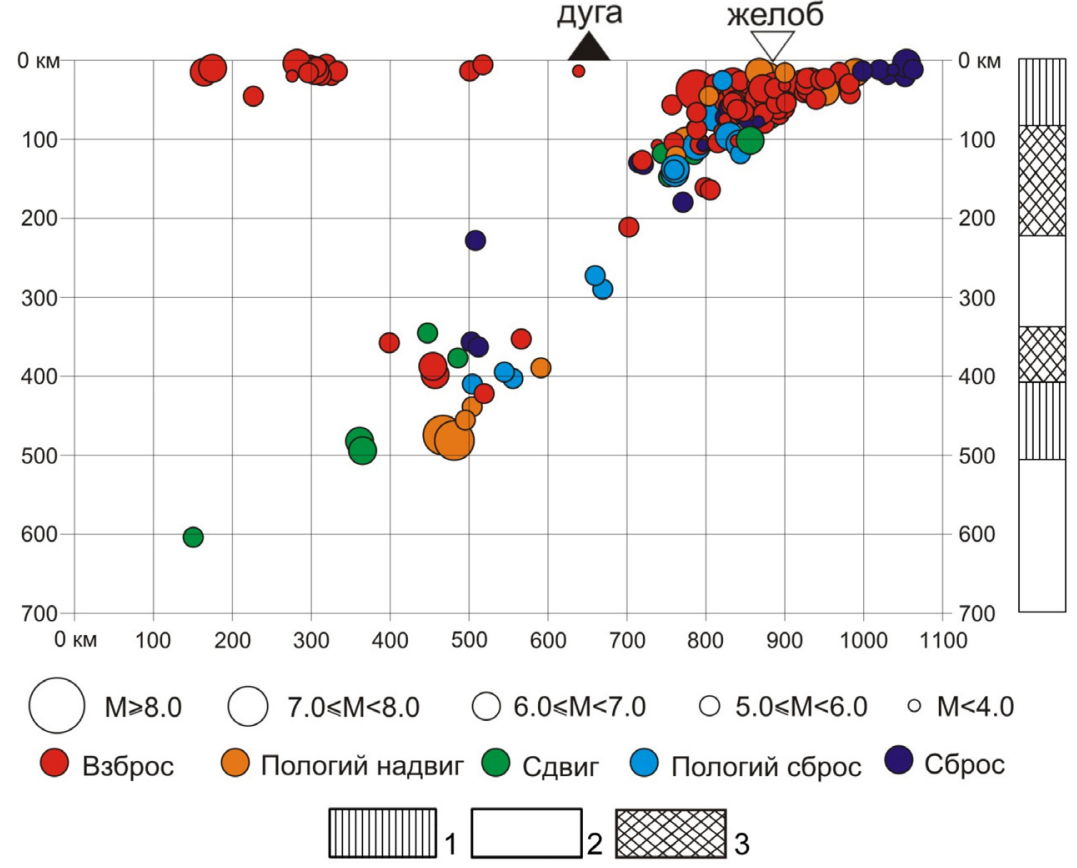

Рис. 3. Схема проекций очагов землетрясений Курило-Охотского региона, согласно данным GCMT, на вертикальные профили, проходящие через Северные (a), Средние (б) и Южные (в) Курильские острова. На шкале справа: 1-3 - подвижки типа взброса и пологого надвига (1), сброса, пологого сброса (2) и смешанного типа (3).

Fig. 3. Projections of earthquake foci of the Kuril-Okhotsk region in vertical profiles across the Northern (a), Middle (б) and Southern (в) Kuril Islands, according to GCMT data. In the scale at the right: 1-3 - fault and low angle reverse fault and gently dipping thrust (1), gently dipping normal fault (2) and mixed-type fault (3). 
претированными механизмами очагов землетрясений резко уменьшается. Эту обширную территорию можно представить двумя областями, обозначенными как № 4 и № 5, разделенными условной линией, ортогональной простиранию дуги (см. рис. 2). В северо-восточной области № 4 преобладают сбросы и условия растяжения, причем из 15 землетрясений 13 имеют сбросовый тип подвижки. В юго-западной зоне № 5 преобладают взбросы. Из общего числа в этой зоне землетрясений (43) с определенными типами подвижек взбросами являются 30.

В западной части зоны № 5 (см. рис. 2) в районе о. Сахалин расположены гипоцентры неглубоких (до 50 км) землетрясений, в основном имеющих взбросовый тип подвижки. Это коровые землетрясения, и они не связаны с СФЗ.

Таким образом, из анализа типов подвижек в очагах землетрясений можно заключить следующее:

1. На основе пространственного распределения типов подвижек в сейсмически активном Курило-Охотском регионе выделено пять зон, из которых три вытянуты вдоль островной дуги, глубоководного желоба и сейсмофокальной зоны и две - западнее островной системы под акваторией Охотского моря. При этом в первой зоне, расположенной под глубоководным желобом и его восточным приокеанским склоном, преимущественно распространены сбросы, соответствующие условиям растяжения. Аналогичный тип подвижек наблюдается в зоне № 3 - под островной дугой и ее приостровным западным склоном.

Зона № 2 представлена в основном взбросовыми подвижками, свидетельствующими об условиях горизонтального сжатия. Зона № 4 соответствует глубинной (более 300-400 км) северо-западной части сейсмофокальной зоны, и здесь преимущественно распространены сбросы, а во второй, юго-западной, № 5, распространены главным образом приповерхностные землетрясения, являющиеся взбросами.

2. Согласно построенным глубинным разрезам гипоцентров землетрясений, в северной, центральной и южной части сейсмофокальной зоны установлен общий характер распределения подвижек по глубинам, который согласуется с распределением их в плане на приведенной карте.

3. Анализ механизмов очагов землетрясений позволяет выявить закономерности распределения ориентировки осей сжатия и растяжения в земной коре и верхней мантии региона.

Особый интерес представляет объяснение выявленных закономерностей распределения землетрясений в пространстве по латерали вдоль дуги и по вертикали сейсмофокальной зоны. При этом отметим, что северные, средние и южные части дуги и СФЗ включают Северные, Средние и Южные Курильские острова. Ниже будем употреблять эти названия как равнозначные.

Рассмотрим типы подвижек сверху вниз по вертикали в СФЗ. Первый слой (0-100 км) отличается по- давляющим количеством взбросов. Они имеют место в интервалах расстояний профиля 750-880 км на Северных Курилах, 850-1050 км в Средних Курилах и 7501000 км в Южных Курилах, причем на Южных Курилах зарегистрированы подвижки типа взброса на глубинах 0-50 км и западнее СФЗ, а также на интервалах профиля 730-150 км, т.е. в земной коре под Курильской котловиной и Сахалином.

Анализ сейсмичности в разных частях Курильской дуги и СФЗ показал, что ее основные особенности выражаются в следующем. На Северных Курилах в интервале глубин 0-100 км в верхней части СФЗ (на расстояниях профиля 750-880 км) распространены взбросы. Ниже, на глубинах от 100 до 170 км, имеют место смешанные подвижки, а на глубинах от 170 до 700 км - сбросы.

Смешанный тип - это область (или зона), в которой имеют место и взбросовые, и сбросовые подвижки. Таким образом, здесь нет однозначного преобладания землетрясений с каким-либо одним из этих типов, а встречаются и те, и другие.

Картина меняется на Средних Курилах. Хотя здесь на глубинах 0-100 км (в интервале ПК 850-1050 км) также взбросы, однако ниже этого этажа, от 100 км до 600 км, наблюдаются сбросы и пологие сбросы, т.е. имеют место условия растяжения. На глубинах от 600 до 700 км преобладают пологие надвиги.

Усложняется распределение землетрясений в Южно-Курильском блоке. Здесь на расстояниях по профилю от 750 до 1000 км в интервале глубин 0-120 км наблюдаются в основном взбросы, а ниже - все виды подвижек.

Ниже 100 км в разных звеньях СФЗ наблюдаются как общие закономерности, так и отличия. Рассмотрим более детально эти особенности с севера на юг.

На Северных Курилах вышеназванные взбросы, связываемые с обстановкой сжатия, имеют место в интервале глубин 0-100 км, а ниже, на глубинах от 100 км до 170 км, они сменяются смешанными подвижками. Здесь наряду со взбросами и пологими надвигами наблюдаются пологие сбросы, а в верхней и нижней части этого второго интервала наблюдаются сдвиги. Соответственно имеют место различные виды напряжения и обстановки.

После глубин 170 км и ниже на всю остальную часть разреза, вплоть до 700 км, наблюдаются сбросовые подвижки, которые связываются с условиями растяжения, сменившими сжатие, имевшее место в вышележащем верхнем этаже. Заметим, что изменению напряженного состояния предшествовал интервал смешанных напряжений и подвижек, проявившихся в различных типах на глубинах 100-170 км.

Разрез Средних Курил, так же как и предыдущий блок, начинается с 100-километрового интервала преимущественно взбросовых подвижек, отражающих условия сжатия. Здесь они наблюдаются на расстояниях по профилю 850-1050 км, т.е. в более широкой зо- 
не, протянувшейся дальше к востоку, что связано, видимо, с изгибом СФЗ, соответствующим положению КОД и желоба.

Следующее существенное отличие Средних Курил от Северных состоит в том, что сразу за распространением взбросовых подвижек наблюдаются практически одни сбросы, причем переход осуществляется без промежуточных смешанных подвижек. При этом сбросы наблюдаются на большом интервале глубин - от 100 до 620 км. Таким образом, большая часть СФЗ на Средних Курилах в рассмотренный период находилась в условиях растяжения, что вполне отвечает тектоническому развитию и строению, связанным с растяжением в средней части КОД и определившим изгиб дуги и ее деформацию. При этом в низах названного интервала на глубине 500-600 км наблюдаются пологие сбросы, как и в вышележащем интервале 100-200 км, где помимо нормальных сбросов, которых большинство, имеются также и пологие сбросы.

Ниже, на глубинах 600-700 км, опять зафиксированы взбросы. Таким образом, условия растяжения, имевшие место на большей части верхней мантии, сменились снова сжатием в ее низах.

Общим для Северных и Средних Курил является превалирование сбросов и соответственно обстановки растяжения на глубинах от 100-200 до 600-700 км, причем этот интервал начинается от 100 км на Средних Курилах и продолжается до 700 км на Северных. Таким образом, в обоих вышеназванных звеньях дуги и СФЗ эта обстановка имела место в общем интервале 200-600 км.

Кроме того, отметим, что практически на всех разрезах СФЗ, построенных различными авторами, а также на приведенных в настоящей работе нет гипоцентров землетрясений на Северных и Средних Курилах в интервале 300-400 км. Авторы допускают, что это связано с отрывом головной части плиты.

Южные Курилы отличаются самой сложной картиной подвижек. Здесь в пределах СФЗ в интервале расстояний по профилю от 750 до 1000 км имеют место самые различные типы подвижек. При этом большая часть подвижек - это взбросы и пологие надвиги. Сбросовые подвижки встречаются по всей глубине от 0-50 до 400 км, а смешанные встречаются в основном в двух диапазонах глубин - от 90 до 210 и от 300 до 410 км. В интервале глубин 220-300 км можно отмечать только сбросовые подвижки, которые связаны с условиями растяжения.

Кроме того, на разных интервалах глубин устанавливаются сдвиги. Они проявляются дискретно. На Северных Курилах сдвиги установлены на глубинах 90120 км, т.е. в зоне смены одного типа (взбросовых) подвижек на другой (сбросовый). Соответственно здесь меняется обстановка горизонтального сжатия на горизонтальное растяжение. На Средних Курилах сдвиги встречаются на глубинах: 0-50 км, 130-160 км, а также 280 км и 500 км. На Южных Курилах сдвиги проявляются также на четырех, как и на Средних Курилах, но несколько иных глубинах. На Северных сдвиги наблюдается в зоне перехода от взбросов к сбросам на глубинах 90-120 км. Таким образом, в проявлении сдвигов в разных частях (блоках) СФЗ наблюдается совпадение. Это имеет место у Южных и Северных Курил на глубинах 100-110 км и 90-120 км, а также у Южных и Средних Курил на глубинах 480-500 км и $500 \mathrm{KM}$.

Первый диапазон, где происходят сдвиговые подвижки, соответствует области смены от горизонтального сжатия к горизонтальному растяжению, которое наблюдается на флангах дуги и СФЗ, а второй - смене растяжения на сжатие в южной и средней части СФЗ. Таким образом, можно отметить, что изменение напряженного состояния сопровождается сдвигами в разных частях СФЗ, что может представлять определенный интерес. Полученные данные систематизированы и представлены ниже в таблице.

Жирным шрифтом в ней показаны интервалы глубин проявления сдвигов, в которых они совпадают и прослеживаются в нескольких блоках СФЗ.

Для анализа и наглядности результатов различных типов подвижек и напряженного состояния, проявляющихся во взбросах (пологих надвигах), сбросах (поло-

Интервалы глубин (км) регистрации сдвигов в Курильском регионе

Depths $(\mathrm{km})$ of displacements registered in the Kuril region

\begin{tabular}{lll}
\hline Интервалы глубин (км) регистрации сдвигов & & \\
\hline Район & & Северные Курилы \\
\hline Южные Курилы & Средние Курилы & $90-120$ \\
$100-110$ & $0-50$ & \\
& $130-160$ & \\
$350-380$ & 280 & \\
$480-500$ & 500 & \\
\hline
\end{tabular}


гих сбросах) и более сложных сочетаниях, обозначим обстановку близгоризонтального сжатия и близвертикального растяжения цифрой 1 , близгоризонтального растяжения и близвертикального сжатия -2 и более сложную - 3 и покажем справа на шкале на рис. 3.

Резюмируя вышесказанное, можно отметить следующее.

1. В распределении сжатия и растяжения в Северных, Средних и Южных Курилах существуют общие черты и определенные различия.

2. Во всех частях СФЗ на глубинах 0-100 км, в интервале профиля от 750-900 до 1050 км, имеют место взбросы и пологие надвиги, т.е. объемы горных пород находятся в обстановке сжатия.

3. Смена типа напряженного состояния в разных частях СФЗ имеет различия. В соответствии с вышеназванной последовательностью напряженного состояния (сжатие, растяжение и сложное), оно может быть выражено следующим образом: Северные Курилы: 1-3-2, Средние Курилы: 1-3-2-1, Южные Курилы - 1-32-3-1.

4. На Северных и Средних Курилах обстановки аналогичны лишь до глубин 600 км, причем состояние 3 во втором звене (блоке) островов выражено очень слабо (лишь наличием двух подвижек типа пологого надвига и взброса).

5. Наиболее простая последовательность наблюдается на Северных Курилах, а сложная - на Южных Курилах. Число смен последовательностей постоянно нарастает - от трех на Северных Курилах до пяти на Южных Курилах, то есть от севера к югу дуги и СФЗ смена типов напряженного состояния учащается.

6. Наиболее протяженный интервал стабильного состояния, около 640 км (от 160 до 800 км), наблюдается на Северных Курилах, наиболее частая (пять раз) и большая смена состояний наблюдается на Южных Курилах.

Таким образом, рассматриваемое катастрофическое событие на Средних Курилах в районе Симушира произошло в условиях смены последовательности напряженных состояний и интервала стабильного состояния, занимающих среднее положение среди других частей СФЗ.

Вышеназванная более частая смена обстановки может быть связана со строением и историей развития островной системы и соответственно СФЗ, а также взаимодействием разных, соседних, крупных геологических структур. Так, Южные Курилы сочленяются со структурами Хоккайдо. Таким образом, здесь граничат две крупные островодужные системы - Курило-Камчатская и Японо-Сахалинская и соответственно две сейсмофокальные зоны. Блок островов Северных Курил - пограничный и лежит в области перехода от Курильской дуги к п-ову Камчатка, которые являются разными ветвями одной и той же Курило-Камчатской дуги. В то же время Средние Курилы являются лишь средней частью системы и структуры КОД и СФЗ. Они граничат с обеих сторон с блоками островов одной и той же структуры, и вышесказанное может объяснять однотипное напряженное состояние и особенности тектонической обстановки. Смена типов напряженных состояний может быть связана и с особенностями истории развития звеньев дуги и сейсмического режима блоков островов на разных глубинах.

\section{3. МОДЕЛИ И СХЕМЫ ЭВОЛЮЦИИ ПЕРЕХОДНЫХ ЗОН И ОСТРОВОДУЖНЫХ СИСТЕМ}

Для объяснения причин различий упругих обстановок были рассмотрены модели и схемы строения структур и их развития в зоне перехода. Как показали исследования, существуют различные модели, объясняющие взаимодействие структур в зоне сочленения континент-океан: модель субдукции [Isacks et al., 1968] (рис. 4, 1); эскалаторная модель (рис. 4, 2); модель ступенчатого поддвига [Liboutry, 1969; Radulescu, 1979] (рис. 5, 3), модель обрушения (рис. 4, 4); модель обдукции [Ollier, 1981] (рис. 4, 5); модель эдукции [Chudinov, 1985] (рис. 4, 6). Кроме того, существуют и иные модели. К ним можно отнести модель триады островная дуга - глубоководный желоб - краевой вал [Hess, 1939]; изгиба или скучивания вещества в слое при его поперечном сжатии; модель, связанную с расплыванием более легкого блока пластического материала поверх более тяжелого и подтеканием последнего [Belousov, 1982]; схему возникновения и развития тектогена [Sheinman, 1968]; геодинамическую схему островодужной системы; схему формирования структур Курильской островной системы [Sergeyev, 1985]; схему вероятного механизма образования наклона сейсмофокальной зоны [Zlobin, 1986]. Одна из последних тектонофизических моделей разработана С.И. Шерманом [Sherman, 2009]. В ней закономерное возникновение отдельных очагов землетрясений объясняется закономерной активизацией разрывов (разломов) и последовательностью расположения очагов землетрясений в каждом из них.

Анализ вышеназванных моделей и схем показывает, что в настоящее время наиболее продуктивным для решения рассматриваемого вопроса в нашем регионе является обращение к модели субдукции (рис. 4, 1). Предпочтение этой модели связано с тем, что, как показывает анализ, именно механизм субдукции может объяснить закономерное распределение зон сжатия и растяжения на рис. 2, 3. Последний вывод подтверждает выполненный Т.К. Злобиным [Zlobin, 1987] натурный эксперимент на Южных Курилах и другие исследования. Приведенный в настоящей работе разрез СФЗ (рис. 5) отвечает результатам изучения распределения землетрясений по типам очаговых подвижек в Курило-Охотском регионе на основе механизмов очагов землетрясений, представленных на рис. 3, 4. Он показывает наличие чередования вытянутых вдоль 

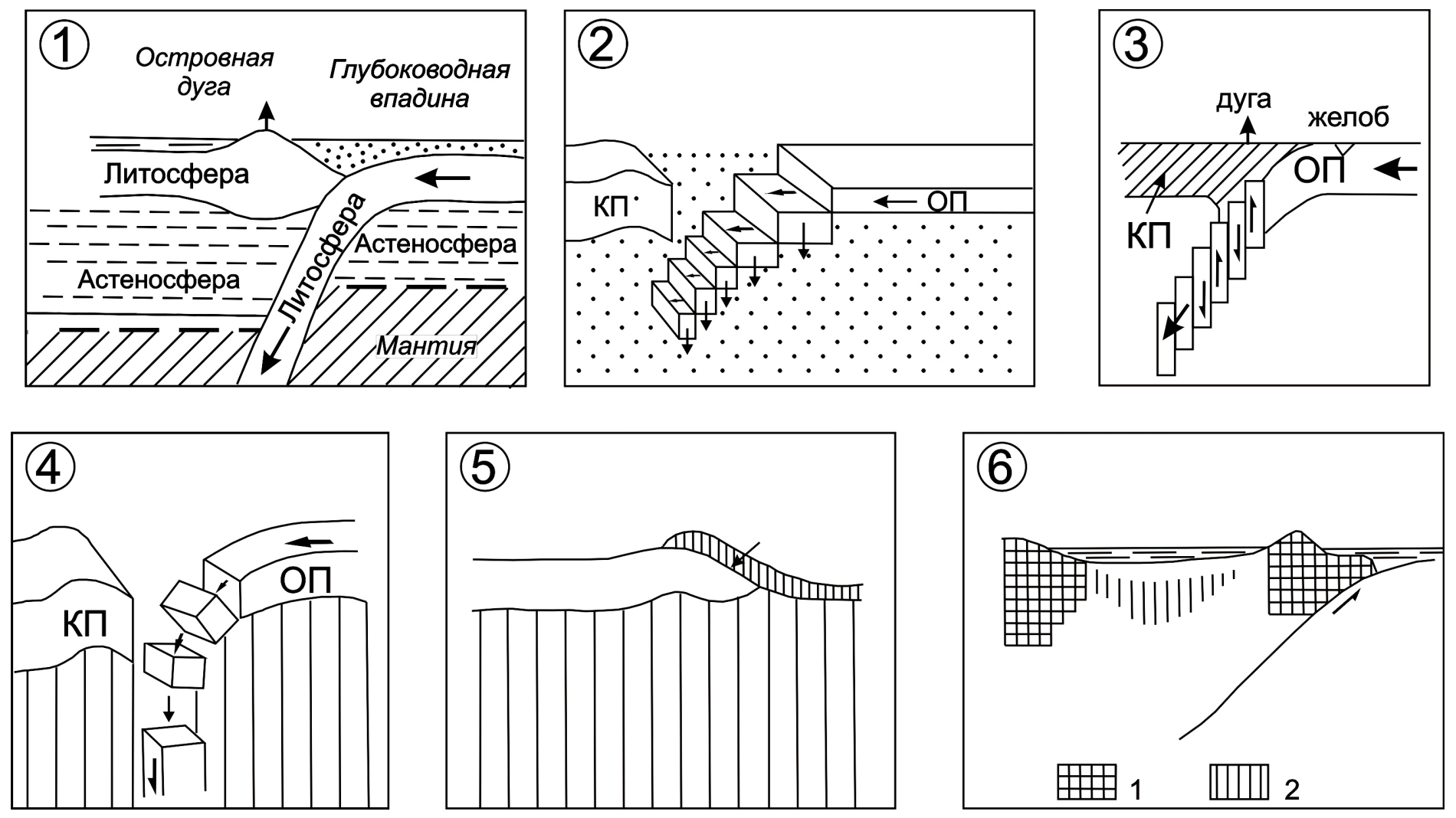

Рис. 4. Основные модели и схемы эволюции переходных зон и островодужных систем. Типы моделей: модель субдукции [Isacks et al., 1968] (1); эскалаторная модель (2); модель ступенчатого подвига [Liboutry, 1969; Radulescu, 1979] (3), модель обрушения (4); модель обдукции [Ollier, 1981] и др. (5); модель эдукции [Chudinov, 1985] (6). Согласно условным обозначениям авторов в модели 4-2 верхняя мантия показана точками, в модели 4-4 и 4-5 - штриховкой, ОП и КП - океаническая и континентальная плита, в модели 4-6 показана континентальная литосфера (1) и участки растяжения (2). Стрелками в моделях показано направление движения плит и ее блоков,

Fig. 4. Basic models and diagrams showing the evolution of transition zones and island-arc systems. Six types of models: 1 - subduction model [Isacks et al., 1968]; 2 - escalation model; 3 - step-wise overthrust model [Liboutry, 1969; Radulescu, 1979]; 4 - collapse model; 5 - obduction model [Ollier, 1981]; 6 - eduction model [Chudinov, 1985]. According to the legend accepted by the authors, the upper mantle is shown in Model 4-2 as dotted areas and in Models 4-4 and 4-5 at hatched areas; OП and КП - oceanic and continental plates in Models 4-6; the continental lithosphere (1) and areas of stretching (2) are shown in Model 4-6. Arrows indicate directions in plate movements and plate blocks in the models.

КОД и СФЗ сменяющихся основных зон растяжения и сжатия, причем как на разрезе вкрест СФЗ на Южных Курилах, так и на схеме (рис. 2), где первая с востока зона растяжения находится под приостровным склоном Курило-Камчатского желоба. Западнее с ней граничит и сменяет ее зона сжатия № 2, расположенная между вышеназванной зоной и островной дугой. При этом далее к западу вновь появляется зона растяжения, соответствующая зоне № 3, расположенной под островодужным поднятием. Наличие же растяжения в зоне глубоководного желоба (зона № 1), возможно, объясняется моделью возвратного движения участка изгиба субдуцирующей плиты согласно В.М. Эльзассеру [E]sasser, 1971].

Таким образом, из вышеприведенных моделей наблюдаемой картине закономерного распределения типов подвижек может отвечать модель субдукции. Она может объяснять чередование зон сжатия и растяже- ния и выявленные особенности распределения землетрясений в островной дуге и сейсмофокальной зоне.

\section{4. Выводы}

1. Анализ механизмов очагов землетрясений в Курило-Охотском регионе, в том числе в районе Средних Курил, где произошло катастрофическое Симуширское землетрясение 15.11.2006 г., позволил установить пространственное распределение и закономерное чередование в регионе типов подвижек в очагах землетрясений. Здесь в целом выделено пять характерных зон, из которых три вытянуты вдоль островной дуги, глубоководного желоба и сейсмофокальной зоны и две - западнее островной системы под акваторией Охотского моря. Результат анализа дает возможность оценить типичность или особенность произошедшего со- 


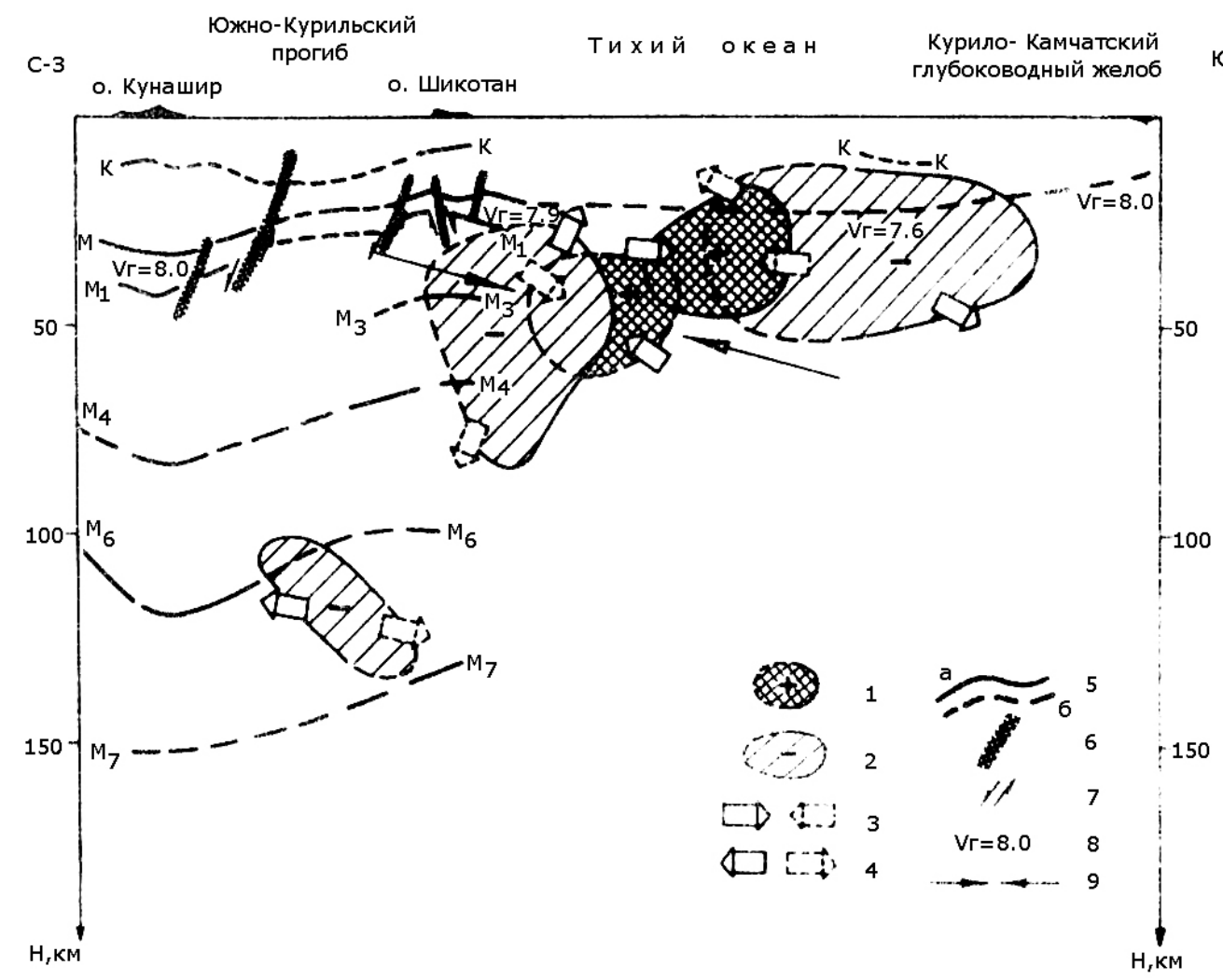

Рис. 5. Разрез земной коры и верхней мантии Южных Курил вкрест простирания островной дуги и распределение зон сжатия и растяжения. 1-2 зоны сжатия (1) и растяжения (2); 3-4 - траектории осей сжатия (3) и растяжения (4); 5 - сейсмические границы по данным MOB3 и ГСЗ, построенные по более уверенным (a) и менее уверенным (б) данным; 6 - разломы; 7 - предполагаемые направления перемещения блоков литосферы; 8 - граничные скорости, км/с; 9 - среднее направление оси сжатия по Л.M. Балакиной [Balakina, 1981].

Fig. 5. The profile of the Earth's crust and the upper mantle across the strike of the Southern Kuril Islands, and the pattern of distribution of horizontal compression and stretching zones. 1 - horizontal compression zones; 2 -zones of stretching zones; 3 - trajectories of compression axes; 4 - trajectories of stretching; 5 - seismic boundaries determined from more confident (a) and less confident (b) data obtained by the converted seismic waves and DSS methods; 6 - faults, 7 - supposed directions of movement of the lithospheric blocks; 8 - boundary velocities, km/sec; 9 - average directions of the compression axis, according to L.M. Balakina [Balakina, 1981].

бытия. Тип подвижки в очаге Симуширского землетрясения 15.11.2006 г. интерпретируется как пологий надвиг, что соответствует условиям сжатия. Из числа рассмотренных событий (515) таких типов подвижек было 32, а произошло рассматриваемое землетрясение в зоне сжатия № 2, которая соответствует области изгиба субдуцирующей плиты.

2. Средние Курилы, где произошло Симуширское землетрясение 15.11.2006 г., среди других частей КОД и СФЗ занимают промежуточное положение по числу изменений напряженного состояния и протяженности интервала стабильного состояния. Наиболее протяженное по глубине стабильное состояние (640 км) и наименьшее число его изменений (2) наблюдаются на Северных Курилах, а наиболее частая (5 раз) смена состояний наблюдается на Южных Курилах, где такие события еще более вероятны, так как с севера на юг картина смены состояний усложняется. Вышеназванные особенности и более частая смена обстановки к югу островной системы и соответственно СФЗ могут быть связаны со строением, историей развития и взаи- модействием отдельных частей и сочленяющихся геологических структур.

3. Первое катастрофическое Симуширское землетрясение (15.11.2006 г., пологий надвиг) было связано с типичными для региона условиями сжатия. Однако через два года после него, 13.01.2007 г., произошло второе катастрофическое событие, которое являлось сбросом и было связано с обстановкой растяжения. Как следует из анализа событий в зоне перехода, эти землетрясения были характерным для нее явлением. Они произошли в разных чередующихся обстановках сжатия и растяжения, более того - между ними проходит граница смены этих зон. Возможно, именно с этим и связан катастрофический характер этих землетрясений, что может говорить о возможности подобных событий на границе выявленных чередующихся зон разного типа напряженного состояния и подвижек в рассмотренном и других аналогичных регионах.

4. Исследование напряженного состояния методом катакластического анализа показало, что подготовка Симуширского землетрясения 15.11.2006 г. произошла 
на участке повышенного уровня эффективного всестороннего давления $p^{*} / \tau_{f}$, граничащем на юге с областью низких напряжений. Очаг землетрясения расположен в пределах этого участка, на границе градиентной зоны. Область подготовки землетрясения в целом достаточно однородна. Области с пониженным уровнем эффективного давления (0-4) с увеличением глубины расширяются и становятся более выраженными, при этом для всех глубинных уровней имеются довольно крупные участки, в пределах которых параметр эффективного всестороннего давления принимает значения, отвечающие среднему уровню, от 4-12.

5. Вышесказанное показывает, при каком напря- женном состоянии, на каком уровне эффективного всестороннего давления, на каком участке и на границе какой зоны может возникнуть очаг катастрофического землетрясения, что может служить одним из критериев для прогноза землетрясений. Модель субдукции наиболее приемлема для нашего региона.

6. Анализ моделей и схем эволюций переходных зон и островодужных систем показывает, что объяснение выявленных закономерностей возможно при применении модели субдукции.

Работа выполнена при поддержке РФФИ (проект № 11-05-98594-р_восток_а).

\section{5. ЛИТЕРАТУРА}

Aver'yanova V.N., 1975. Deep seismotectonics of island arcs. Nauka, Moscow, 219 p. (in Russian) [Аверьянова В.Н. Глубинная сейсмотектоника островных дуг. М.: Наука, 1975. 219 с.].

Balakina L.M., 1981. Mechanisms of interim earthquakes in the Kuril-Kamchatka focal zone. Fizika Zemli 8, 3-24 (in Russian) [Балакина Л.M. Механизмы очагов промежуточных землетрясений Курило-Камчатской фокальной зоны // Физика Земли. 1981. № 8. С. 3-24].

Belousov V.V., 1982. Transition zones between continents and oceans. Nedra, Moscow, 150 p. (in Russian) [Белоусов В.В. Переходные зоны между континентами и океанами. М.: Недра, 1982. 150 с.].

Chudinov Yu.V., 1985. Geology of active oceanic margins and global tectonics. Nedra, Moscow, 248 p. (in Russian) [Чyдuнов Ю.В. Геология активных океанических окраин и глобальная тектоника. М.: Недра, 1985. 248 с.].

Elsasser W.M., 1971. See-floor spreading as thermal convection. Journal Of Geophysical Research 76 (5), 1101-1112. http://dx.doi.org/10.1029/Jb076i005p01101.

Fedotov S.A., Chernyshev S.D., 1987. 20 years of long-term seismic forecasting for the Kuril-Kamchatka arc: reliability in 1981-1985 in general for 1965-1985 and a forecast for 1986-1990. Vulkanologiya i Seismologiya 6, 93-109 (in Russian) [Федотов С.А., Чернышев С.Д. 20 лет долгосрочного сейсмического прогноза для Курило-Камчатской дуги: достоверность в 1981-1985 гг., в целом за 1965-1985 гг. и прогноз на 1986-1990 гг. // Вулканология и сейсмология. 1987. № 6. C. 93-109].

Hess G.G., 1939. Island arcs, gravity anomalies and serpentinite intrusion (to the problem of ophiolites). In: Proceedings of the XVII session of the IGC. V. II. GONTI, Moscow, p. 279-300 (in Russian) [Хесс Г.Г. Островные дуги, аномалии силы тяжести и интрузии серпентинитов (к проблеме офиолитов) // Труды XVII сессии МГК. Т. II. М.: ГОНТИ, 1939. С. 279-300].

Isacks B., Oliver J., Sykes L.R., 1968. Seismology and the New Global Tectonics. Journal of Geophysical Research 73 (18), 5855-5899. http://dx.doi.org/10.1029/JB073i018p05855.

Liboutry L., 1969. Sea-floor spreading, continental drift and lithosphere sinking with an asthenosphere at melting point. Journal of Geophysical Research 74 (27), 6525-6540. http://dx.doi.org/10.1029/JB074i027p06525.

Ollier C.D., 1981. Tectonics and landforms. Longman, London-New York, 324 p.

Polets A.Yu., 2011. The study of tectonic direction and deep seismotectonics in the southern and central parts of the KurilOkhotsky region. Thesis of Candidate of Physics and Mathematics. Moscow, 24 p. (in Russian) [Полец А.Ю. Исследование тектонических напряжений и глубинной сейсмотектоники южной и центральной части Курило-Охотского региона: Автореф. дис. ... канд. физ.-мат. наук. М., 2011. 24 с.].

Poplavskaya L.N., Bobkov A.O., Boichuk A.N., Mitaleva N.A., Oskorbin L.S., Rudik M.I., Strel'cov M.I., Tikhonov I.N, Malyshev A.I., 1991. The Simushir earthquake of 09 January 1989. Institute of Marine Geology and Geophysics RAS, Yuzhno-Sakhalinsk, 54 p. (in Russian) [Поплавская Л.Н., Бобков А.О., Бойчук А.Н., Миталева Н.А., Оскорбин Л.С., Рудник М.И., Стрельцов М.И., Малышев А.И. Симуширское землетрясение 9 января 1989 года. Южно-Сахалинск: Институт Морской геологии и геофизики ДВО РАН, 1991. 54 с.].

Radulescu D.P., 1979. Volcanoes Today and in the Geological Past. Nedra, Moscow, 255 p. (in Russian) [Рэдулеску Д.П. Вулканы сегодня и в геологическом прошлом. М.: Недра, 1979. 255 с.]

Rebetsky Yu.L., 2007. Tectonic stresses and strength of natural rock massifs. Akademkniga, Moscow, 406 p. (in Russian) [Ребецкий Ю.Л. Тектонические напряжения и прочность природных горных массивов. М.: ИКЦ «Академкнига», 2007. 406 c.].

Rebetsky Yu.L., 2009. Stress state of the Earth’s Crust of the Kuril Islands and Kamchatka before the Simushir earthquake. 
Russian Journal of Pacific Geology 3 (5), 470-476. http://dx.doi.org/10.1134/S1819714009050108.

Sergeyev K.F., 1985. On the mechanism of formation of the Kuril island system. Tikhookeanskaya Geologiya 1, 62-71 (in Russian) [Сергеев К.Ф. О механизме образования Курильской островной системы // Тихоокеанская геология. 1985. № 1. C. 62-71].

Sheinman Yu.M., 1968. Essays on the deep geology. Nedra, Moscow, 231 p. (in Russian) [Шейнман Ю.М. Очерки глубинной геологии. М.: Недра, 231 с.].

Sherman S.I.. 2009. A Tectonophysical model of a seismic zone: Experience of development based on the example of the Baikal rift system. Izvestiya, Physics of the Solid Earth 45 (11), 8-21. http://dx.doi.org/10.1134/S1069351309110020.

The Global CMT Project. Available from http://www.globalcmt.org/ (last accessed May 20, 2012).

Tikhonov I.N., Vasilenko N.F., Zolotukhin D.E., Ivelskaya T.N., Poplavsky A.A., Prytkov A.S., Spirin A.I., 2008. Simushir earthquakes and tsunami of November 15, 2006, and January 13, 2007. Russian Journal of Pacific Geology 2 (1), 1-14. http://dx.doi.org/10.1134/S1819714008010016.

Zlobin T.K., 1986. The nature of the slope of the Benioff seismic focal zones, and the probable mechanism of their formation. Doklady AN SSSR 289 (3), 689-692 (in Russian) [Злобин T.K. Природа наклона сейсмофокальных зон Беньофа и вероятный механизм их образования // Доклады АН СССР. 1986. Т. 289. № 3. С. 689-692].

Zlobin T.K., 1987. The structure of the Earth's crust and upper mantle in the Kuril island arc (according to seismic data). Dal'nevostochnyy Nauchnyy Tsentr AN SSSR, Vladivostok, 150 p. (in Russian) [Злобин T.К. Строение земной коры и верхней мантии Курильской островной дуги (по сейсмическим данным). Владивосток: ДВНЦ АН СССР, 1987. 150 с.].

Zlobin T.K., Levin B.W., Polets A.Yu., 2008. First results of the comparison of catastrophic Simushir earthquakes on November 15, $2006(M=8.3)$, and January 13, $2007(M=8.1)$, with the deep structure of the Earth`s crust in the central Kuril Islands. Doklady Earth Sciences 420 (4), 615-619. http://dx.doi.org/10.1134/S1028334X08040193.

Zlobin T.K., Poplavskaya, Polets A.Yu., 2009. A series of strong and catastrophic Simushir earthquakes, 2006-2009: General features and seismotectonics of the source zones. Doklady Earth Sciences 428 (7), 1227-1231. http://dx.doi.org/10.1134/ S1028334X09070411.

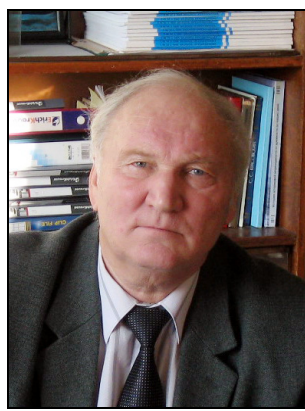

Злобин Тимофей Константинович, докт. геол.-мин. наук, г.н.с.

Институт морской геологии и геофизики ДВО РАН

693022, Южно-Сахалинск, ул. Науки, 1б, Россия

Тел.: 89147527290; $₫$ e-mail: t.zlobin@mail.ru

Zlobin, Timofei K., Doctor of Geology and Mineralogy, Chief Researcher Institute of Marine Geology and Geophysics, Far East Branch of RAS 693022, Yuzhno-Sakhalinsk, Nauka street, 1b, Russia

Tel.: 89147527290; $\bowtie$ e-mail: t.zlobin@mail.ru

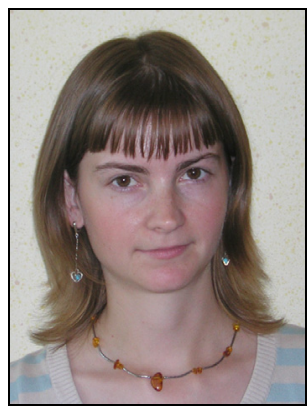

Полец Анастасия Юрьевна, канд. физ.-мат. наук, м.н.с.

Институт морской геологии и геофизики ДВО РАН

693022, Южно-Сахалинск, ул. Науки, 1б, Россия

Тел.: 89242833454; e-mail: polec84@mail.ru

Polets, Anastasia Yu., Candidate of Physics and Mathematics, Junior Researcher Institute of Marine Geology and Geophysics, Far East Branch of RAS

693022, Yuzhno-Sakhalinsk, Nauka street, 1b, Russia

Tel.: 89242833454; e-mail: polec84@mail.ru 